Journal

of Geography,

Politics and Society

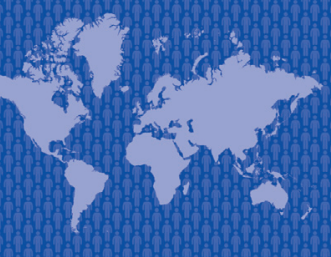

$8(4) / 2018$
Journal of Geography, Politics and Society

$2018,8(4), 32-36$

DOI 10.4467/24512249JG.18.026.9013

\title{
CROSS-BORDER HEALTH SERVICES - SELECTED ISSUES
}

\section{Paulina Jaszczuk}

Collegium luridicum, Faculty of Law, Canon Law and Administration, John Paul II Catholic University of Lublin in Lublin, Spokojna 1, 20-074 Lublin, Poland, e-mail: jaszczuk.paulinaa@gmail.com

\section{Citation}

Jaszczuk P., 2018, Cross-border health services - selected issues, Journal of Geography, Politics and Society, 8(4), 32-36.

\begin{abstract}
One of the superior principles in integrated Europe is free flow of persons, services and capital. An expression of this freedom are regulations about coordination of social security systems binding both in EU and EFTA member states. The principles of granting health services and their scope are determined by the provisions about coordination of social security systems. In the article I will try to discuss the most important regulations regarding the issues related to cross-border health care, both EU regulations and the related provisions of the domestic law.
\end{abstract}

\section{Key words}

health, health services, cross-border health services

Received: 09 July 2018

Accepted: 25 August 2018

Published: 30 November 2018

\section{Introduction}

In the age of contemporary, in principle substantially unlimited, travel opportunities across Europe, an important role is played by cross-border health services. Each of us being abroad can become ill, may experience an injury, or accident. Health as a superior value is subject to particular protection. In my article I will try to synthesize the regulations governing the indicated problems related to crossborder health services as well as demonstrate that these provisions do not allow an ordinary citizen to fully use cross-border health services.

It is worth emphasising that one of human rights is the right to health, which is provided by the most important legal acts both on the domestic and international level (e.g. ICCPR). The Constitution of the
Republic of Poland', in Article 68 section 1, guarantees the right to health protection to every citizen. It is a basic right, resulting from inherent and inalienable human dignity. As indicated by A. Rabiega (2009), the functioning of the democratic state of law inseparably involves the necessity to respect the values which are both life and health, and the obligation to protect such rights rests on the state. In this context it is important to protect health through the implementation of cross-border health services.

\footnotetext{
1 Konstytucja Rzeczypospolitej Polskiej z dnia 2 kwietnia 1997 r., (Dz. U. Nr 78, poz. 483 ze zm.)
} 


\section{Cross-border health services in the light of the EU law}

At the beginning of the deliberations, it should be indicated that one of the superior principles in integrated Europe is free flow of persons, services and capital. An expression of this freedom are regulations about coordination of social security systems binding both in EU and EFTA member states. The principles of granting health services and their scope are determined by the provisions about coordination of social security systems. Coordination consists in introducing and applying principles common for all member states, which determine the terms of receiving medical assistance by the patient (having the right to health care benefits in their country). They also allow each of the UE member states to retain its own, previously binding social and health security system (Kowalska-Mańkowska, 2018).

Coordination of the benefits provided under social security systems assumes granting the given individual access to health services to the extent they could use such benefits in their home country. In addition national authorities are obliged to respect and exercise the individual's right to receive health care when staying abroad, at the same time, it should be pointed out that it is of no importance whether the person uses the benefits granted by a public, or a private institution, if they are refunded in the home country (Tabaszewski, 2016).

In accordance with the content of Article 35 of the Charter of Fundamental Rights of the European Union, everybody has the right to access prophylactic health care and the right to use treatment on the terms of established in domestic legislations and practices $^{2}$. As indicated by R. Tabaszewski (2016), the language interpretation of this provision excludes differentiation of the status of EU citizens and other persons.

The EU legislator also, in Article 168 of the Treaty on the Functioning of the European Union (TFUE), indicates that, when determining and pursuing all the policies and actions of the European Union, a high level of protection of human health is ensured ${ }^{3}$. The action of the European Union which supplements national policies, is focused on improvement in public health as well as among others monitoring serious cross-border health hazards, early warning in the case of such hazards and combating them. Moreover, in accordance with Article 168 section

\footnotetext{
2 Karta Praw Podstawowych Unii Europejskiej, Dz.U.UE.C.2007.303.1.

3 Traktat o funkcjonowaniu Unii Europejskiej, Dz.U.2004.90.864/2, Dz.U.UE.L.2016.200.137
}

2, the European Union encourages the EU member states to cooperate in the fields of public health and supports any actions taken in this respect, also in particular encouraging collaboration between the EU member states in order to improve complementarily of their health services in border regions.

It should be noted, that pursuant to Article 6 letter a of TFUE, the competence of the European Union in public health is only supporting, coordinating and supplementary in nature towards the member states' actions. Therefore, performance of these competences consists, on the one hand, in receiving recommendations, opinions, resolutions, conclusions, messages, while on the other hand in financing member states' actions (Stankiewicz, 2016).

EU's basic derivative legislation governing the matters related to cross-border health care is Directive of the European Parliament and the Council 2011/24/EU of 9 March 2011 on exercising patients' rights in cross-border health care ${ }^{4}$.

The purposes of the directive include: establishing principles to facilitate patients' access to safe cross-border health care, ensuring patients' mobility, promoting cooperation in health care between the member states, with full respect for the competences of the member states in organization and provision of health care (Transgraniczna...). In addition, the primary goal is elimination of barriers in access to health protection for member states' citizens moving between UE states. The Directive establishes principles ensuring equal, non-discriminating access to high quality safe cross-border health care.

Essential for this discussion is also the legal definition of "the insured person". Clearly, according to the vocabulary of the definition from Article 1 of the Regulation of the European Parliament and the Council (EC) no. 883/204 of 29 April 2004 on coordination of social security systems it is each person meeting the conditions required on the basis of the laws of the Member State to have the right to benefits ${ }^{5}$.

It should be indicated that the insured person in one UE/EFTA member state is entitled to - while temporarily staying in a different UE/EFTA member state than the state of insurance, namely residence - use the material benefits which have become necessary in the course of such stay from the medical point of view, subject to the nature of these benefits

\footnotetext{
4 Dyrektywa Parlamentu Europejskiego i Rady 2011/24/UE z dnia 9 marca 2011 r. w sprawie stosowania praw pacjentów w transgranicznej opiece zdrowotnej, Dz.U.UE.L.2011.88.45

5 Rozporządzenie Parlamentu Europejskiego i Rady (WE) nr 883/204 z dnia 29 kwietnia 2004 r. w sprawie koordynacji systemów zabezpieczenia społecznego, Dz.U.UE.L.2004.166.1, Dz.U.UE-sp.05-5-72
} 
and duration of the stay, to be granted in order to avoid situations when the patient would be forced to return to the territory of the state of insurance to obtain treatment. Such benefits should thus be described as unplanned. It seems necessary while staying abroad in connection with a sudden illness, an unexpected deterioration of the existing chronic disease or an accident ${ }^{6}$ (Kowalska-Mańkowska, 2018).

\section{Cross-border health services and the Polish law}

Issues associated with health care benefits granted outside the borders of Poland have also been regulated in the domestic law and more specifically in chapter 2a of the Act of 26th August 2004 on health care services financed from the public funds ${ }^{7}$.

Even before implementing the Cross-Border Directive E. Nojszewska pointed to the disadvantages and advantages of the introduced regulations, stressing the disadvantages of the new solutions being additional costs for the health care system related to the need to perform institutional - administrative obligations resulting from the directive (among others establishment of contact points or starting cooperation between the specified institutions). As the advantages, she regarded among others the possibility to pay for the benefits granted abroad using the domestic rates (Nojszewska, 2011).

Regulations implementing the Cross-Border Directive have given the Polish patients the possibility to claim back the costs of the provided health care, but subject to the specified conditions, namely the given benefit in Poland is included in the catalog of guaranteed services, the benefit has been granted within the area of another UE member state. In addition, it should be noted that this opportunity can only be used by persons who are able to finance the performed services on their own, because the funds from the National Health Fund (NFZ) are received in the form of a refund. In performing some benefits limitations have also been introduced in applying for refund of costs by introducing the required prior approval, granted in the form of an administrative decision by the director of the National Health Fund (NFZ) Branch (NIK informacja..., 2017) ${ }^{8}$.

\footnotetext{
6 EFTA - European Free Trade Association.

7 Ustawa z dnia 26 sierpnia 2004 r. o świadczeniach opieki zdrowotnej finansowanych ze środków publicznych, Dz.U.2017.1938 j.t.

8 eng. NIK information on the post-control results, Respecting patients' rights in cross-border health care, LOP.430 001.2017, Register no. 45/2017/P/16/084/LOP, Warsaw, 29.06.2017
}

According to the ruling of the Provincial Administrative Court in Warsaw of 27 October 2017 when stating that the given health care benefit is not in the guaranteed services basket, as included in the respective, due to date of resolution of the case, Regulation of the Minister of Health, the authority is under the obligation to refuse refund of the treatment costs in the above indicated procedure. The beneficiary, on the basis of Article 42b of the act from 2004 on health care services financed from public funds, is only authorized to refund of the costs of benefits being guaranteed services (VI SA/Wa 1323/17). In the case concerned the National Health Fund Branch, examining the documentation, stated that the treatment concerned consisted in performing prosthetic supplements, which are not guaranteed services in Poland pursuant to the binding legal act, namely the Regulation of the Minister of Health of 6 November 2013 on guaranteed dental treatment services. The President of the National Health Fund also confirmed that the completed surgery was not within the scope of guaranteed services which the beneficiary is entitled to receive the refund for ${ }^{9}$.

It should be noted that pursuant to Article 42d section 2 item 6 of the act of 26 August 2004 on health care services financed from public funds ${ }^{10}$ the beneficiary is obligated to present documents containing sufficient date concerning the diagnostic or therapeutic process, allowing identification of the health care services related to the application for reimbursement of costs, and in the event of no cooperation from the party in this regard with the authority, the binding regulations envisage adverse effects for the party, namely issuing the decision on refusing refund of the costs by the director of the provincial branch of the National Health Fund. It clearly results from this provision that in the procedure for reimbursement of costs mentioned in Article $42 \mathrm{~b}$ of the act on benefits, the burden of proof with regard to the data concerning the diagnostic or therapeutic process, necessary to identify the health care services related to the application for reimbursement of costs, rests with the applicant party.

In addition, it should be indicated that the matters related to insurance are strictly administrative cases, which has been clearly stressed by the Supreme Court in the decision of 28 May $2015^{11}$, where

\footnotetext{
9 Wyrok Wojewódzkiego Sądu Administracyjnego w Warszawie z dnia 27 października 2017 r., VI SA/Wa 1323/17, LEX nr 2446506.

10 Ustawa z dnia 26 sierpnia 2004 r. o świadczeniach opieki zdrowotnej finansowanych ze środków publicznych, Dz.U.2017.1938 j.t.

11 Postanowienie Sądu Najwyższego z dnia 28 maja 2015 r., III CZP 26/15, LEX nr 1764817, Biul.SN 2015/8/10
} 
it indicated that the case for reimbursement of costs of treatment granted abroad, in spite of its property nature, is not a civil case as defined by Article 1 and 2 of the Code of Civil Procedure, as the recipient of this claim can only be the state as a public law entity. Therefore, any case for reimbursement of costs of treatment granted abroad is an administrative case, to be resolved under the administrative procedure.

What is significant for the right of the party applying for refund of costs on the basis of Article $42 \mathrm{~b}$ of the act of 2004 on health care services financed from public funds, it is of no importance whether the beneficiary went to another member state of the European Union in order to obtain health services, or the treatment was not to be the main objective of the trip ${ }^{12}$.

The cross-border directive assumes costs refund to the level to which the costs would be covered by the member state of insurance if the same health care was provided on its territory and in such amount as not to exceed the actual cost of the received health care. Freedom has been left for the member states with regard to refund of costs in the full amount as well as in coverage of the costs of accommodation and travel. The National Health Fund is authorized to make refund of costs for the beneficiary in the amount it would finance the given benefit within the agreements concluded for the provision of health care services with Polish service providers ${ }^{13}$. The application for reimbursement of costs is submitted within 6 months from the day of issuing the bill for provided health care the application relates to.

It should also be noted that there is the institution named the National Contact Point, responsible for any cross-border health care matters. It is an institution operating in each UE member state. Its tasks include, among others provision of information and assistance to persons which intend to or have already used health services on the terms specified in the cross-border directive (Dyrektywa...).

In addition, patients can also apply for reimbursement of costs of drugs or medical products purchased in another UE country based on a prescription issued by a Polish doctor, or one from another UE country. The same thing applies to a prescription issued by a doctor from another UE state and realized in a Polish pharmacy. The refund is concerned with medicines reimbursed in Poland, according to the announcement of the Minister of Health valid on

\footnotetext{
12 Wyrok Wojewódzkiego Sądu Administracyjnego z dnia 27 maja 2016 r., VI SA/Wa 250/16, LEX nr 2113749.

13 Wyrok Wojewódzkiego Sądu Administracyjnego z dnia 27 maja 2016 r., VI SA/Wa 250/16, LEX nr 2113749.
}

the day of realizing the prescription in the pharmacy. "Cross-border" prescription is issued on the same print as the "regular" prescription, valid in a particular country (Dyrektywa...).

The Supreme Chamber of Control has also made a statement about treatment abroad. It has been clearly indicated in the conclusions from the completed inspections that the introduction of the cross-border directive allowing Polish patients to obtain refund of costs for treatment in other countries of the European Union has not significantly increased access to health services. The main barrier in using fully the possibility of treatment abroad is, in their opinion, the need to independently finance the treatments by the patients who are then refunded treatment costs by NFZ after the end of treatment. Briefly referring to the statistics, it should be indicated that in the years 2014-2017 (until February) all NFZ branches received only 86 applications concerning prior consent to benefits planned outside the borders of Poland. At the same time it has to be stressed that only one consent to treatment abroad, later changed on the patient's request, resulting in applying the regulations on coordination of social security systems and not the procedure established as a result introducing the cross-border directive (NIK o leczeniu..., 2017).

In the post-control conclusions, NIK (Supreme Chamber of Control) indicated the need to simplify the procedure for examination of the applications for reimbursement of costs of health care obtained in an UE member state other than the Republic of Poland and making of the refunds as well as to develop and implement mechanisms providing persons, who have used health care outside the borders of Poland and require further medical observation, access to the observation what would be provided in the case of using health care on the state's territory (NIK o leczeniu..., 2017).

It should also be noted that the right to health protection which, as earlier indicated, is a right of each person, is not identical with the right to health services financed by public funds which is only granted to Polish citizens. Persons not meeting the criterion of citizenship have guaranteed access to health services, but with the exception of these benefits which are financed by public funds (Jaroszyński, 2016).

\section{Conclusions}

To sum up, it should be stated that cross-border health care is ensured by both domestic and European regulations, which I have referred to above. 
It should be indicated that this is a proper solution providing travelling citizens access to medical care. However, as it results from the statistics quoted by NIK, few people use the opportunity of using medical services in the European Union member countries. This can result from among others small awareness of people in this respect and concerns that even if there is a possibility to use a particular service abroad, these costs will not be refunded. Perhaps, it would be reasonable to e.g. start activities described in Article, promoting the possibility to use medical services outside Poland, e.g. by presenting how the procedure of applying for refund of such benefits looks like. It seems that some actions in this respect could also be performed by local government units as, according to the principle of decentralization of public authority, some public authority rights and responsibilities are transferred from state authorities to local government authorities on as low level as possible.

\section{References}

Dyrektywa Parlamentu Europejskiego i Rady 2011/24/UE z dnia 9 marca 2011 r. w sprawie stosowania praw pacjentów w transgranicznejopiece zdrowotnej, Dz.U.UE.L.2011.88.45.

Dyrektywa Transgraniczna, /no data/, Narodowy fundusz Zdrowia Zachodniopomorski Oddział Wojewódzki w Szczecinie, Szczecin, http://www.nfz-szczecin.pl/nguqv_dyrektywa_transgraniczna.htm [08.08.2018].

Jaroszyński J., 2013, Finansowanie produktów leczniczych w Polsce, [in.] M. Szewczak, B. Drop, R. Śmiech (eds.), Prawo w ochronie zdrowia. Doświadczenia i perspektywy rozwoju, Wydawnictwo KUL, Lublin, 197-254.

Karta Praw Podstawowych Unii Europejskiej, Dz.U.UE.C.2007.303.1.

Konstytucja Rzeczypospolitej Polskiej z dnia 2 kwietnia 1997 r. Dz. U. Nr 78, poz. 483 uniform text.

Kowalska-Mańkowska I., 2018, Komentarz do art.42(a) ustawy o świadczeniach opieki zdrowotnej finansowanych ze środków publicznych, [in.] A. Pietraszewska-Macheta (ed.), Ustawa o świadczeniach opieki zdrowotnej finansowanych ze środków publicznych. Komentarz, WPK LEX.

NIK informacja o wynikach po kontroli, 29.06.2017 r., Respektowanie praw pacjentów $w$ transgranicznej opiece zdrowotnej, LOP.430.001.2017, Nr ewid. 45/2017/P/16/084/LOP, Warszawa.

NIK o leczeniu za granica, 2017, Najwyższa Izba Kontroli, Warszawa, https://www.nik.gov.pl/aktualnosci/nik-o-leczeniu-za-granica.html [04.07.2018].

Nojszewska E., 2011, Funkcjonowanie systemu ochrony zdrowia w Polsce na tle wybranych krajów europejskich, [in.] K. Ryć, Z. Skrzypczak (ed.), Ochrona zdrowia na świecie, Wolters Kluwer Polska, Warszawa, 49-90.

Postanowienie Sądu Najwyższego z dnia 28 maja 2015 r., III CZP 26/15, LEX nr 1764817, Biul.SN 2015/8/10.
Rabiega A., 2009, Ochrona życia i zdrowia ludzkiego w działaniach podmiotów administrujących w sferze opieki zdrowotnej, Wydawnictwo Sejmowe, Warszawa.

Rozporzq̨dzenie Parlamentu Europejskiego i Rady (WE) nr 883/204 z dnia 29 kwietnia 2004r. w sprawie koordynacji systemów zabezpieczenia społecznego, Dz.U.UE.L.2004.166.1, Dz.U.UE-sp.05-5-72.

Stankiewicz R., 2016, Krajowe systemy ochrony zdrowia a Unia Europejska. Przykład Polski, Wolters Kluwer Polska.

Tabaszewski R., 2016, Prawo do zdrowia w systemach ochrony praw człowieka, Wydawnictwo KUL, Lublin.

Traktato funkcjonowaniu Unii Europejskiej, Dz.U.2004.90.864/2, Dz.U.UE.L.2016.200.137.

Transgraniczna opieka zdrowotna, /no data/, Rzecznik Praw Pacjenta, Warszawa, https://www.bpp.gov.pl/dla-pacjenta/transgraniczna-opieka-zdrowotna/ [03.07.2017].

Ustawa z dnia 26 sierpnia 2004 r. o świadczeniach opieki zdrowotnej finansowanych ze środków publicznych, Dz.U.2017.1938 uniform text.

Wyrok Wojewódzkiego Sądu Administracyjnego w Warszawie z dnia 27 października 2017 r., VI SA/Wa 1323/17, LEX nr 2446506.

Wyrok Wojewódzkiego Sądu Administracyjnego z dnia 27 maja 2016 r., VI SA/Wa 250/16, LEX nr 2113749. 